\title{
ANALISIS PRESUPOSISI PADA PERCAKAPAN MAHASISWA FKIP UNPRI TAHUN AJARAN 2019/2020
}

\author{
oleh:
}

\section{Nanda Dwi Astri (nandadwiastri@unprimdn.ac.id)}

\begin{abstract}
ABSTRAK-Tujuan penelilitian ini untuk mendeskripsikan presuposisi dalam percakapan mahasiswa FKIP UNPRI.Metode yang digunakan dalam ini adalah metode kualitatif. penelitian. Pengumpulan data penelitian dilakukan dengan menggunakan tehnik simak. Data disimak dengan menggunakan bantuan alat rekam dan catatan. Sementara itu, analisis data yang digunakan adalah melalui kriteria penentu bentuk tindak tutur praanggapan. Berdasarkan analisis hasil penelitian dapat dijabarkan sebagai berikut. (1) Tindak tutur praanggapan yang ditemukan dalam percakapan Mahasiwa FKIP UNPRI. (2) Presuposisi eksistensial, faktif, leksikal, nonfaktif, struktural, konterfaktual. Dalam komunikasi Mahasiswa FKIP UNPRI ditemukan jenis deklarasi. Hal tersebut disebabkan tidak ditemukan bentuk tuturan yang menghubungkan isi tuturan dengan kenyataan.
\end{abstract}

Kata Kunci: Tindak tutur, presuposisi, percakapan mahasiswa

\section{A. Pendahuluan}

Bahasa sebagai salah satu media untuk berkomunikasi harus jelas maknanya, tujuannya, dan maksudnya agar informasi yang disampaikan kepada lawan tutur dapat dipahami. Memahami makna dalam sebuah tuturan merupakan hal yang esensial yang dapat memudahkan penutur dan mitra tutur memahami informasi yang disampaikan dalam berkomunikasi melalui simbol-simbol bahasa. Bahasa berfungsi sebagai alat komunikasi. Komunikasi yang dimaksud tidak hanya dalam bidang resmi pemerintahan, tetapi juga dalam kehidupan sehari-hari. Bahasa tersusun dari kodekode dan simbol-simbol yang konvensional sifatnya karena dasar pembentukannya adalah kesepakatan penuturnya. Hasil konvensi kebahasaan itu tersusun rapi dalam daftar leksikon sehingga dengan mudah orang kembali kepada kamus ketika tidak mengerti maknanya, namun masih terdapat penggunaan bahasa yang tidak terdapat dalam kamus tetapi, pemakaiannya selalu muncul dalam percakapan masyarakat. Dasar pembentukannya juga tidak jelas dan bukan merupakan konvensi secara global. Hal ini disebabkan pembentukan bahasa secara arbiter.

Menurut Rahardi (2006: 112) mengemukakan bahwa itulah sebabnya pembentukan bahasa arbitrer sifatnya. Menurut Jabrohim (2012:15) mengemukakan bahwa, "Bahasa yang dipergunakan secara istimewa dalam ciptaan sastra, pada hakikatnya, dalam rangka fungsi sastra berperan sebagai sarana komunikasi, yaitu untuk menyampaikan informasi." Selain itu, di dalam pembelajaran bahasa Indonesia dibutuhkan interaksi antara guru dengan siswa supaya pembelajaran yang berlangsung mencapai hasil yang maksimal.

Pragmatik adalah satu di antara cabang kajian ilmu linguistik yang membahas tentang pemaknaan kalimat secara menyeluruh. Dalam kajian pragmatik, pemaknaan sebuah percakapan 
tidak hanya terpaku pada makna percakapan baik secara verbal maupun tekstual, tapi ada makna lain yang terkandung dalam percakapan tersebut. Makna lain tersebut terjadi karena adanya faktor eksternal dari kalimat percakapan seperti situasi tutur atau pengalaman dari pelaku percakapan tersebut. Penggunaan bahasa yang berkaitan dengan situasi tutur (speech situation), di mana penutur menuturkan tuturan dan berkaitan dengan situasi tutur ketika percakapan tersebut terjadi. Kalimat yang diucapkan penutur bisa dianggap tidak dapat dimengerti secara aturan berbahasa, tapi mitra tutur dapat mengerti maksud yang diucapkan oleh penutur.

Hal tersebut mengakibatkan pemaknaan yang berbeda dari makna kalimat yang disampaikan oleh penutur dan mitra tutur juga mengerti apa maksud sebenarnya tuturan tersebut karena mitra tutur menangkap makna yang terkandung di luar kalimat tersebut. Cabang ilmu pragmatik terdiri atas tindak tutur, implikatur, dan praanggapan. Searle (dalam Rohmadi, 2010:34) menjelaskan tindak tutur adalah produk atau hasil dari suatu kalimat dalam kondisi tertentu dan merupakan kesatuan terkecil dari komunikasi linguistik yang dapat berwujud pernyataan, pertanyaan, perintah atau nyang lainnya. Tindak tutur atau tindak ujar berdasarkan jenisnya dibedakan menjadi lima, yaitu representatif, direktif, ekspresif, komisif, deklarasi.

Pragmatik memiliki beberapa kajian yaitu deiksis, presuposisi, tindak tutur, dan implikatur percakapan (Sumarsono, 2004:87). Kajian pragmatik yang menjadi objek penelitian ini adalah presuposisi. Praanggapan (presuposisi) berasal dari kata to pre-suppose, yang dalam bahasa Inggris berarti to suppose beforehand (menduga sebelumnya), dalam arti sebelum pembicara atau penulis mengujarkan sesuatu ia sudah memiliki dugaan sebelumnya tentang lawan bicara atau hal yang dibicarakan. Menurut Yule (2006:43), presuposisi adalah sesuatu yang diasumsikan oleh penutur sebagai kejadian sebelum menghasilkan suatu tuturan. Artinya, sebelum terjadi sebuah tuturan, maka adanya suatu kejadian yang memicu tuturan tersebut. Sejalan dengan pendapat Yule tersebut, jika presuposisi tersebut dikaitkan dalam tuturan, Wijana (1996:37) memberikan penjelasan bahwa sebuah kalimat yang dinyatakan mempresuposisikan kalimat yang lain jika ketidakbenaran kalimat yang kedua (kalimat yang dipresuposisikan) mengakibatkan kalimat pertama (kalimat yang mempresuposisikan) tidak dapat dikatakan benar atau salah.

Yule (2006:46) mengklasifikasikan presuposisi menjadi enam jenis, yaitu presuposisi eksistensial (existensial presupposition), presuposisi faktif (factivepresupposition), presuposisi leksikal (lexical presupposition), presuposisi struktural (structural presupposition), presuposisi nonfaktif (non-factive presupposition), dan presuposisi konterfaktual (conter-factual presupposition). Presuposisi eksistensial (existensial presupposition) adalah presuposisi yang mengasosiasikan suatu keberadaan. Presuposisi faktif (factivepresupposition) adalah presuposisi yang berupa informasi yang dipraanggapkan mengikuti kata kerja dapat dianggap sebagai suatu kenyataan. Presuposisi leksikal (lexical presupposition) adalah presuposisi yang diperoleh melalui tuturan yang diinterpretasikan melalui penegasan dalam 
tuturan. Presuposisi nonfaktif (non-factive presupposition) adalah presuposisi yang diasumsikan tidak benar. Presuposisi struktural (structural presupposition) adalah presuposisi yang dinyatakan melalui tuturan yang strukturnya jelas dan langsung dipahami tanpa melihat kata-kata yang digunakan. Selanjutnya, presuposisi konter-faktual

(conter-factual presupposition) adalah sesuatu yang dipresuposisikan tidak hanya tidak benar, tetapi juga bertolak belakang dengan kenyataan (Yule, 2006:46-51).

Berkenaan dengan penelitian ini, peneliti mengkaji presuposisi yang terdapat dalam percakapan mahasiswa FKIP UNPRI. Percakapan adalah komunikasi interaktif antara dua orang atau lebih atau kegiatan bicara atau pembicaraan yang dilakukan dua orang atau lebih. Dalam percakapan yang mengandung presuposisi, antara penutur dan mitra tutur harus memiliki pemahaman yang sama terhadap informasi yang akan dimaksudkan oleh penutur. Dengan kata lain antara penutur dan mitra tutur memiliki informasi yang sama terhadap suatu masalah yang akan dibicarakan. Selanjutnya mitra tutur dapat memprediksi dan memiliki asumsi awal tentang apa yang akan diucapkan oleh penutur karena mitra tutur memiliki informasi yang sama dengan mitra tutur sebelum memulai percakapan.

Dalam kehidupan sehari-hari, manusia tidak lepas dari kegiatan berbicara sebagai jembatan dalam berkomunikasi. Manusia perlu berbicara untuk menyampaikan gagasan dan perasaannya. Menurut Musaba (2012: 4), seseorang dikatakan mampu berbicara jika ia dapat mengemukakan segala ide atau buah pikiran serta perasaan dengan jelas kepada orang lain. Wacana percakapan tidak dapat dihindari oleh manusia karena setiap manusia membutuhkan segala kebutuhannya untuk mencapai tujuan hidupnya. Hal ini disampaikan oleh manusia melalui percakapan. Menurut Jumadi (2010: 49), wacana percakapan adalah interaksi lisan bersemuka antara dua partisipan atau lebih untuk mencapai tujuan tertentu.

Praanggapan terjadi saat seorang penutur mengucapkan tuturan kepada mitra tutur. Tuturan yang diungkapkan oleh penutur dapat diindikasikan mengandung presuposisi potensial. Presuposisi potensial adalah ungkapan dari penutur yang diindikasikan mengandung presuposisi. Kemudian akan menjadi presuposisi sebenarnya dalam konteks dengan penutur. Sehingga dapat dikatakan presuposisi terdapat pada penutur, bukan terdapat pada mitra tutur atau tuturan yang diungkapkan oleh mitra tutur. Praanggapan merupakan sesuatu ujaran yang mengandung makna kebenaran atau ketidakbenaran sesuai dengan tuturannya. Rahardi (2005: 42) mengatakan sebuah tuturan dapat dikatakan mempraanggapkan tuturan yang lain apabila ketidakbenaran tuturan yang dipresuposisikan mengakibatkan kebenaran atau ketidakbenaran tuturan yang mempresuposisikan tidak dapat dikatakan.

Praanggapan dipelajari untuk mengetahui maksud yang terkandung dalam sebuah wacana atau tuturan yang maknanya tidak mampu dijelaskan oleh teori semantik dengan didukung konteks dan koteks. Tuturan-tuturan dalam kalimat yang secara lahiriah tidak berkaitan, namun bagi yang mengerti penggunaan bahasa atau pesan yang disampaikan tersebut dapat dipahami karena memiliki pengetahuan yang sama antara penutur dan lawan tutur. Di dalam bertutur kesopanan 
juga dilihat, yang dimaksud sopan dalam bertutur adalah informasi yang disampaikan dalam tutur tidak dikatakan secara jelas dan terang-terangan, melainkan secara tersirat. Khusus kajian praanggapan memegang peranan peting di dalam menetapkan keruntutan atau koherensi.

Menurut Filmore (dalam Rani, dkk. 2010: 268) mengemukakan bahwa praanggapan adalah asumsi-asumsi atau interferensi-interferensi yang tersirat dalam ungkapan-ungkapan linguistik tertentu. Dalam setiap percakapan selalu digunakan tingkat-tingkat komunikasi yang implisit atau praanggapan dan eksplisit atau ilokusi. Dengan membuat praanggapan yang tepat dapat dipertinggi nilai komunikatif dalam sebuah ujaran yang diungkapkan. Semakin tepat praanggapan yang dihipotesiskan, semakin tinggi pula nilai komunikasi suatu ujaran, sebaliknya kesalahan membuat praanggapan mempunyai efek dalam ujaran yang dapat menimbulkan koherensi yang tidak komunikatif. Pentingnya peranan praanggapan dipelajari dan dikaji agar dapat memberikan nuansa pemahaman yang dapat dipahami oleh penutur dan mitra tutur dalam berkomunikasi. Jadi dalam praanggapan, sebelum sang penutur mengucapkan atau mengujarkan sesuatu, dia sudah memiliki dugaan sebelumnya tentang respon mitra bicara terkait hal yang dibicarakan.

Berdasarkan uraian yang telah dikemukakan, peneliti tertarik dan memilih judul untuk mengkaji masalah ini karena agar dapat memudahkan dalam memahami makna yang tersirat dari suatu percakapan dan perlu mengetahui presuposisi yang ada. Selain itu hasil penelitian yang peneliti peroleh dapat memberikan pengetahuan yang lebih kepada pembaca serta dapat memberikan pemahaman yang baik dan menjadi referensi kepada pembaca tentang presuposisi. Karena didalam percakapan mahasiswa atau pada saat mereka melakukan tindak tutur banyak kata-kata atau kalimat yang mereka sampaikan mengandung arti atau atau makna yang lawan berbicaranya atau lawan tutur tidak mengetahui maksudnya dan mengakibatkan lawan tutur menjadi salah beranggapan.

\section{B. METODE PENELITIAN}

Penelitian ini merupakan penelitian kualitatif. Data penelitian ini berupa tuturan dalam artinya penelitian ini bertujuan untuk mendeskripsikan objek yang akan diteliti yang mengenai percakapan penutur dan mitra tutur yang melatarbelakangi suatu tindak tutur yang terdapat dalam percakapan Mahasiswa FKIP UNPRI. Data penelitian ialah meliputi lisan dan data tertulis. Data lisan diperoleh dengan mendengar, dan menganalisis hasil percakapan mahasiswa FKIP UNPRI. Data tulis diperoleh dari hasil yang sudah dianalisis, dikumpulkan dengan menggunakan metode simak yaitu penelitian menyimak penggunaan bahasa. Teknik pengumpulan data yang penulis gunakan adalah Teknik Simak Bebas Libat Cakap yaitu penulis menyimak penggunaan bahasa tanpa ikut berpartisipasi dalam proses pembicaraan. Penulis melanjutkan dengan teknik catat (Mastoyo, 2007: 44).

Penulis menganalisis data dengan metode padan. Metode padan adalah metode analisis data yang alat penentunya di luar, terlepas, dan tidak menjadi bagian dari bahasa (Sudaryanto, 1993: 13). Jenis metode padan yang penulis pakai adalah metode padan pragmatis yaitu metode padan yang alat penentunya lawan atau mitra bicara. Metode ini digunakan untuk 
mengidentifikasi presuposisi pada tuturan yang sering digunakan pada mahasiswa FKIP UNPRI.

\section{HASIL DAN PEMBAHASAN \\ 1. Presuposisi Eksistensial}

Istilah eksistensial berasal dari akar kata ex-sistere, yang secara literal berarti bergerak atau tumbuh ke luar. Dengan istilah ini hendak dikatakan oleh para eksistensialis bahwa eksistensi manusia seharusnya dipahami bukan sebagai kumpulan substansi-substansi, mekanismemekanisme, atau pola-pola statis, melainkan sebagai "gerak" atau "menjadi", sebagai sesuatu yang "mengada". Yule (2006:46) menyebutkan presuposisi eksistensial (existential presupposition) merupakan presupposisi yang ada tidak hanya diasumsikan terdapat dalam susunan possesif, tetapi juga lebih umum atau lebih luas lagi ke dalam frasa nomina tertentu. Praanggapan ini menunjukkan kepemilikan, tetapi lebih luas lagi keberadaan atau eksistensi dari pernyataan dalam tuturan tersebut. Pra-anggapan eksistensial menunjukkan bagaimana keberadaan atas suatu hal dapat disampaikan lewat praanggapan. Misalnya pada contoh tuturan berikut.

Ira: "Tante saya memiliki mobil avanza keluaran terbaru."

Diana : "Bagus kalau begitu."

Praanggapan dalam tuturan tersebut menyatakan kepemilikan, yaitu Tante Ira memiliki mobil. Apabila Tante ira memang benar memiliki mobil avanza keluaran terbaru, maka tuturan tersebut dapat dinyatakan keberadaannya.

\section{Praanggapan Faktual}

Yule (2006:46) menyebutkan presuposisi faktual dengan presuposisi faktif. Menurut Yule, presuposisi faktif adalah informasi yang dipraanggapkan yang mengikuti kata kerja dapat dianggap sebagai kenyataan. Mengingat tuturan tersebut belum tentu kata kerja, bisa juga menggunakan kata sifat. Menurut Kridalaksana (1993:54), faktif berarti verba yang mempunyai komplemen kalimat dan yang menyimpulkan kebenaran komplemen itu. Presuposisi faktual (factive presupposition) muncul dari informasi yang ingin disampaikan dinyatakan dengan kata-kata yang menunjukkan suatu fakta atau berita yang diyakini kebenarannya. Kata-kata yang bisa menyatakan fakta dalam tuturan adalah kata sifat yang dapat memberikan makna pasti dalam tuturan tersebut. Misalnya pada contoh tuturan berikut :

$$
\text { Lenny sangat mencintai }
$$

kekasihnya. Apapun yang diminta oleh pacarnya, ia turutin. Sampai padadisuatu titik, Lenny tidak menyadari bahwa hal itu melukai hatinya. Sebab, kekasih Lenny meminta persetujuan kepadanya untuk memiliki selingkuhan.

Rizky: "Lenny, apakah saya boleh selingkuh?"

Lenny: "Iya boleh mas"

Dalam tuturan di atas, praanggapannya adalah Lenny sedang terluka. Pernyataan itu menjadi faktual karena telah disebutkan dalam tuturan. Penggunaan kata "luka" dari tuturan "Lenny tidak menyadari bahwa hal itu melukai hatinya" merupakan kata sifat yang dapat diyakini kebenarannya.

\section{Praanggapan Leksikal}

Makna leksikal merupakan makna dasar sebuah kata yang sesuai dengan kamus. Makna dasar ini melekat pada kata dasar sebuah kata. Yule (2006:47) menjelaskan, pada umumnya di dalam presuposisi leksikal (lexical presupposition), pemakaian suatu bentuk dengan makna yang dinyatakan secara konvensional ditafsirkan dengan 
pressuposisi bahwa suatu makna lain (yang tidak dinyatakan) dipahami. Praanggapan ini merupakan praanggapan yang didapat melalui tuturan yang diinterpretasikan melalui penegasan dalam tuturan. Bedanya dengan presuposisi faktual, tuturan yang merupakan presuposisi leksikal dinyatakan dengan cara tersirat sehingga penegasan atas praanggapan tuturan tersebut bisa didapat setelah pernyataan dari tuturan tersebut.

Contoh 1:

Mey memiliki kebiasaan minum es. Ia tidak pernah berhenti menghabiskan sebungkus es dalam waktu satu hari. Namun karena kebiasaan buruknya itu, Mey mengalami sakit yang cukup parah dan akhirnya dia memutuskan untuk tidak mengonsumsi es lagi.

Ernia: "Kamu sakit apa, Mey?

Mey: "Radang tenggorokan karena minum banyak es."

Ernia: "Cepat sembuh ya. Jangan minum es lagi."

Mey: "Iya, tidak lagi kok."

Praanggapan dari tuturan di atas yaitu Mey adalah seorang peminum es. praanggapan tersebut muncul dengan adanya penggunaan kata "tidak" dari tuturan "tidak mengonsumsi es lagi" yang menyatakan bahwa dulu Mey pernah minum es dan sekarang sudah minum es lagi.

Contoh 2:

Akhir-akhir ini Diana sering terlambat tidur dan bergadang hingga larut malam. Dia tidak biasanya seperti ini, akibatnya dia sering terlambat masuk kuliah karena sulit untuk dibangunkan dipagi hari. Karena mengakibatkan terlambat untuk mengikuti perkuliahan, maka Diana berhenti bergadang dan tidur tepat pada waktunya.
Praanggapan dari tuturan di atas adalah dulu Diana tidak pernah tidur larut malam. Praanggapan tersebut muncul dengan adanya penggunaan kata "berhenti" dari tuturan "Diana berhenti bergadang" yang menyatakan bahwa dulu Diana sering bergadang, namun sekarang ia sudah mengubah pola tidurnya dengan tidur tepat waktu.

\section{Presuposisi Non Faktif}

Non berarti sesuatu yang bersifat negatif atau bertentangan. Nonfaktual berarti tidak faktual. Berarti nonfaktual ialah sesuatu yang tidak sesuai kenyataan, atau sesuatu yang tidak mengandung kebenaran. Presuposisi nonfaktual (nonfactive presupposition) menurut Yule (2006:50) merupakan suatu pressuposisi yang diasumsikan tidak benar. Praanggapan ini masih memungkinkan adanya pemahaman yang salah karena penggunaan kata-kata yang tidak pasti dan masih ambigu.Presuposisi non-faktif adalah suatu peranggapan yang di asumsikan tidak benar.

Contoh 1:

Fitri sudah menjalani hubungan dengan pacarnya selama 10 tahun. Ia sering membayangkan duduk di pelaminan bersama pacarnya. Namun kenyataannya berbanding terbalik, Fitri melihat pacarnya duduk di pelaminan dengan wanita lain.

Igayana: "Hey Fit, kenapa kamu melamun?"

Fitri: "Eh, tidak apa-apa." (sambil berkata dengan gugup)

Praanggapan yang muncul dari tuturan tersebut adalah Fitri tidak duduk di pelaminan. Penggunaan tuturan "Ia sering membayangkan sedang duduk di pelaminan bersama pacarnya" bisa memunculkan praanggapan nonfaktual, karena kalimat tersebut memunculkan praanggapan mengenai keadaan yang tidak 
sesuai dengan kenyataannya yaitu melihat pacarnya duduk di pelaminan dengan wanita lain.

Contoh 2:

Igay selalu membayangkan akan tempat wisata di Paris dan ingin bertempat tinggal disana, begitu merasa bahagianya jika tinggal disana. Namun sayangnya, itu hanyalah hayalan semata. Nyatanya Igay sedang berada di kampus dan tidak berada diParis.

Adinda: "Igay, kamu sedang dimana?" Igayana: "Saya sedang berada di Paris."

Adinda: "Bukannya kamu sedang di kampus?"

Igaya: "Maaf, iya saya lagi di kampus."

Praanggapan yang muncul dari tuturan tersebut adalah Igay tidak berada di Paris. Penggunaan tuturan "Igay selalu membayangkan akan tempat wisata di Paris dan ingin bertempat tinggal disana" bisa memunculkan praanggapan nonfaktual, karena kalimat tersebut memunculkan praanggapan mengenai keadaan yang tidak sesuai dengan kenyataannya yaitu Igay sedang berada di kampus.

Contoh 3: Kalaulah saya punya banyak uang

Peranggapan pada tuturan diatas menunjukkan "saya tidak punya banyak uang". Peranggapan kalaulah disisni sebagai pengandaian dapat memunculkan peranggapan non-faktif yang kebenarannya masih diragukan dengan fakta yang disampaikan.

\section{Presuposisi Struktural}

Presuposisi stuktural adalah peranggapan yang mengacu pada stuktur kalimat-kalimat tertentu yang telah di analisis sebagai peranggapan yang menetap dan konvensiona namun denga syarat bahwa bagian stuktur itu sudah diasumsikan kebenarannya. Hal ini diketahui dari kata tanya (kapan dan dimana) sudah diketahui sebagai masalah. Penutur disini dapat menggunakan struktur-struktur yang sedemikian untuk melakukan informasi seperti yang di prasangkakan (karena di anggap benar) dan dari sini bisa diterima oleh penutur.

Tipe struktural ini juga dapat menuntun penutur untuk mempercayai bahwa informasi yang disajikan pasti benar, bukan seperti peranggapan seseorang yang sedang bertanya. Presuposisi struktural (structural presupposition) merupakan struktur kalimat-kalimat tertentu yang telah dianalisis sebagai pressuposisi secara tetap dan konvensional bahwa bagian struktur itu sudah diasumsikan kebenarannya (Yule, 2006:49). Praanggapan struktural merupakan praanggapan yang dinyatakan melalui tuturan yang strukturnya jelas dan langsung dipahami tanpa melihat katakata yang digunakan.

Contoh :

Dimalam hari, Samsul pergi keluar rumah untuk membeli sebungkus nasi goreng di pinggir jalan dekat rumahnya dan akan diberikan kepada kekasihnya, Sari. Dimalam yang sama, dia pergi mengantarkan nasi goreng itu kerumah Sari yang cukup jauh jaraknya dari tempat tinggal Samsul. Namun itu tidak menjadi alasan, karena prinsip Samsul yaitu jarak dan waktu tidak menjadi suatu penghalang untuk mereka berjumpa.

Sari: "Bang, Sari lapar."

Samsul: "Bentar ya biar abang belikan nasi goreng."

Tuturan di atas menunjukkan praanggapan, yaitu ada sebungkus nasi goreng. Praanggapan yang menyatakan "nasi gorengee sebagai obyek yang dibicarakan dapat dipahami oleh penutur melalui struktur kalimat yang menyatakan 
"pergiee. Selain itu terdapat makna "tempate dalam tuturan "Samsul pergi keluar rumah untuk membeli sebungkus nasi goreng di pinggir jalan dekat rumahnya" yang bisa saja mengandung makna bahwa membeli nasi goreng tidak harus selalu jauh dari rumah tempat tinggal.

\section{Presuposisi Konterfaktual}

Presuposisi konterfaktual adalah peranggapan yang tidak hanya benar,tetapi bisa jadi kebalikan (lawan) ataupun bertolak belakang dari kenyataan. Kata konter memiliki makna menantang atau melawan. Menurut Yule (2006: 51), presuposisi konterfaktual (counterfactual presupposition) adalah apa yang dipraanggapkan tidak hanya tidak benar, tapi kebalikan (lawannya) dari benar, atau bertolak belakang dengan kenyataan. Praanggapan ini adalah praanggapan yang menghasilkan pemahaman yang berkebalikan dari pernyataannya atau kontradiktif.

Contoh:

Ernia yang sehari-hari bekerja sebagai supir ojek online. Ia sering bergumam dalam hatinya sambil berkata "Seandainya aku punya uang, kemudian aku belikan buku-buku yang banyak. Pasti akan aku manfaatkan buku-buku itu sebaik mungkin."

Dari contoh tuturan di atas, dapat dilihat praanggapan yang muncul adalah sekarang Ernia tidak memiliki uang. Praanggapan tersebut muncul dari kontradiksi kalimat dengan adanya penggunaan tuturan "Seandainya aku punya uang". Penggunaan kata "seandainya"e membuat praanggapan yang kontradiktif dari tuturan yang disampaikan.

\section{Kesimpulan}

Implikasi percakapan akan sangat mungkin sekali muncul dalam suatu percakapan, terlebih lagi dalam suatu kelompok mahasiswa tertentu. Dalam suatu kelompok sosial yang didalamnya sudah terdapat berbagai faktor yang memunculkan suatu kedekatan tertentu antar anggotanya, sangat memungkinkan sekali terjadi suatu implikatur percakapan dalam proses komunikasi yang terjadi. Dapat dikatakan, bahwa faktor-faktor tertentu termasuk kedekatan, akan mempengaruhi suatu bentuk komunikasi yang terjadi.

Praanggapan adalah kesimpulan atau asumsi awal penutur sebelum melakukan tuturan bahwa apa yang disampaikan dapat dipahami oleh mitra tuturnya. Sebuah tuturan dapat dikatakan mempresuposisikan atau mempraanggapkan tuturan lainnya, apabila ketidakbenaran tuturan yang dipraanggapkan itu mengakibatkan kebenaran atau ketidakbenaran tuturan tidak dapat dikatakan sama sekali.

\section{Saran}

Semoga tulisan ini dapat bermanfaat bagi pembaca. Dengan adanya pembahasan ini diharapkan agar dalam berinteraksi sosial pragmatis khususnya praanggapan bisa membantu untuk terjalinnya komunikasi yang baik. Penulis mengharapkan kepada semua pembaca untuk mempelajari praanggapan agar dapat menambah ilmu pengetahuan yang lebih luas. Dengan mempelajari hal diatas diharapkan pembaca dapat memahami apa yang dimaksud dengan praanggapan sehingga dapat diterapkan dalam kehidupan sehari-hari.

\section{Daftar Pustaka}

Jabrohim, 2012. Teori Penelitian Sastra. Yogyakarta: Pustaka Pelajar. 
Jumadi. 2010. Wacana: Kajian Kekuasaan Berdasarkan Ancangan Etnografi Komunikasi dan Pragmatik. Yogyakarta: Pustaka Prisma.

Kesuma, Tri Mastoyo Jati. 2007. Pengantar (Metode) Penelitian Bahasa. Yogyakarta. Carasvatibooks.

Musaba, Zulkifli. 2012. Terampil Berbicara: Teori dan Pedoman Penerapannya. Yogyakarta: CV. Aswaja Pressindo.

Rahardi, Kunjana. 2006. Dimensi-Dimensi Kebahasaan. Yogyakarta: Erlangga.

Rahardi, R.K. (2005). Pragmatik Kesantunan Imperatif Bahasa Indonesia. Jakarta. Erlangga.

Rani, Abdul, dkk. 2010. Analisis Wacana: Sebuah Kajian Wacana dalam Pemakaian. Malang: Bayumedia.

Sudaryanto. 1993. Metode dan Aneka Teknik Analisis Bahasa (Pengantar Penelitian Wahana Kebudayaan secara Linguistik). Yogyakarta: Duta Wacana University Press.

Sumarsono. 2004. Buku Ajar Filsafat Bahasa. Jakarta: PT Grasindo.

Wijana, I.D.P, dan Muhammad R. 2009. Analisis Wacana Pragmatik Kajiaan Teori dan Analisis. Surakarta: Yuma Pustaka.

Yule, George. 2006. Pragmatik. Yogyakarta: Pustaka Pelajar. 